\title{
Black-Eyed Susan
}

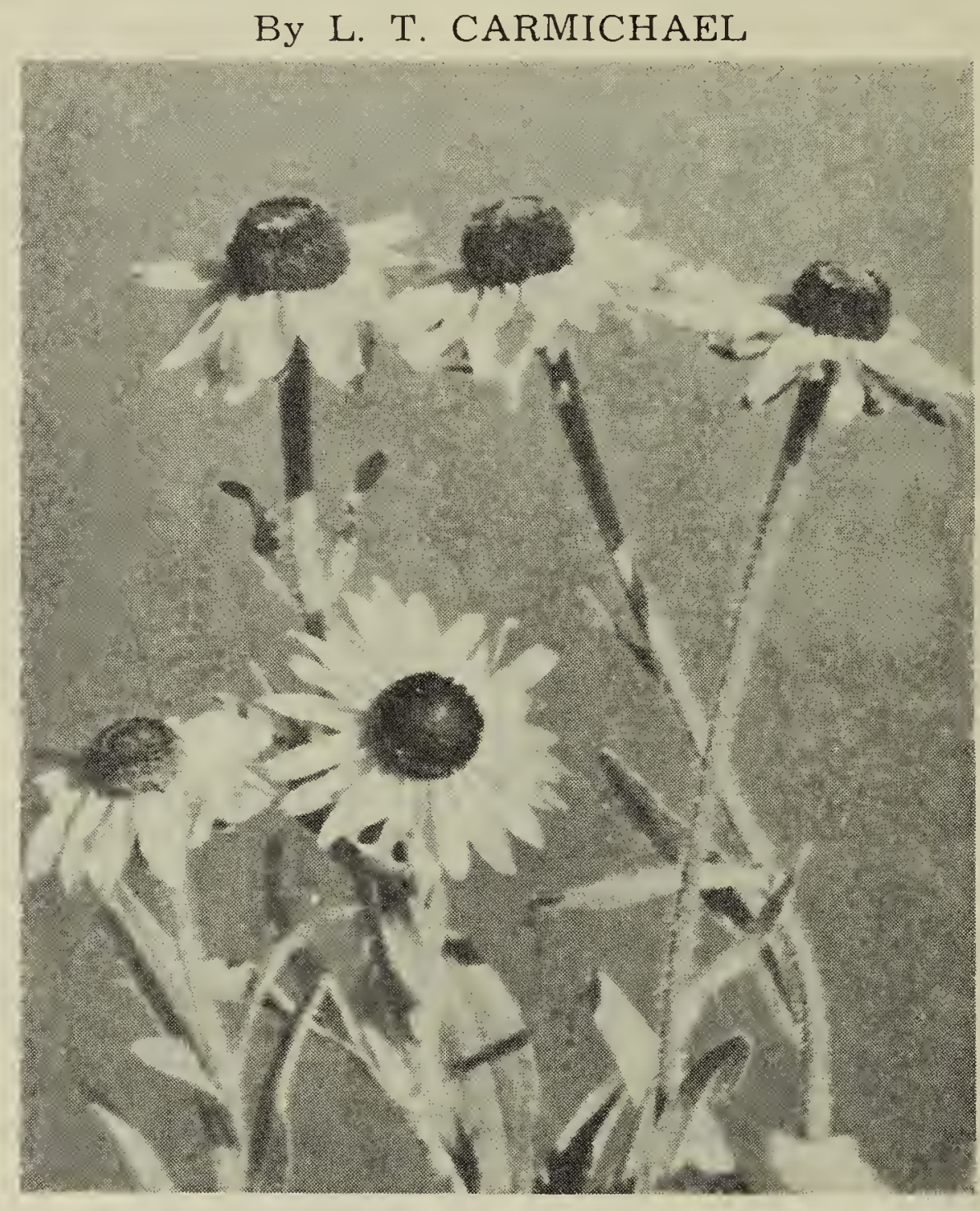

-Photo by L. T. Carmichael

Among our conspicuous plants blooming during the months of June and July are a closely related group of golden-tinted flowers of the compositae family, the Gaillardia or Blanket-flower, the Prairie Coneflower, and the Black-eyed Susan (Rudbeckia hirta). The first two named are very common on the open prairie, but throughout this area the Black-eyed Susan thrives only in low sheltered grassy meadows. The greater beauty of these large gold and chocolate flower heads and rough foliage more than compensates for its scarcity and always solicits unbounded admiration. I know of only one meadow near Regina where these flowers grow profusely. Their ray-florets are almost a brilliant orange against a setting of the delicate pink blossoms of the Western Snowberry and a mass of quiveringleaved aspens growing along the bank of a sluggish stream.

They seem to be fitting companions to our floral emblem, the Prairie Lily, which together with the snow-white Canada Anemone, and the pale yellow lily-like flowers of the Smooth Camas, bloom in the same area, on the same type of soil and at the same time.

The people who live in the woodlands of Eastern Saskatchewan, or throughout the central and northcentral park lands are more fortunate, for in these areas the Blackeyed Susan is a fairly common flower of the meadows and roadsides.

\section{Black-Eyed Susan}

Nigger brown and flashing gold, Standing there in accent bold,

Without a doubt the brightest gem In Nature's sparkling diadem.

In twos and threes, neath sunny skies. You captivate with dark brown eyes All passers-by, and fill with bliss Because your charms they can't resist.

G. W. Carmichael, Montreal 